\title{
Editor's Message \\ The role of field camp in an evolving geoscience curriculum in the United States
}

\author{
Frederick D. Day-Lewis, Associate Editor
}

Many geoscience departments in the United States are reexamining their curricula in light of declining enrollments and shifting employment patterns. There has been a clear trend in geology-related industry away from mineral and petroleum geology and toward water supply, environmental remediation, and hazard mitigation. In response to these changes, many geology departments are embracing emerging subdisciplines such as biogeochemistry and remote sensing. Many are also adding new faculty and courses, integrating new technology into course labs, and growing into departments that address the full range of modern geoscience. With more universities encouraging or requiring geology students to take additional courses in calculus, differential equations, statistics, GIS, and computer programming, the composition of the geology core curriculum is in flux. Indeed, the requirements for a university degree in geology vary widely. While some departments offer several options and provide students flexibility to target their interests and career objectives, other departments cling firmly to the traditional core geology curriculum. The latter argue that a full suite of courses in physical geology, historical geology, mineralogy, structural geology, sedimentology, petrology, and paleontology are requisite background for any geoscience career. As programs struggle through this identity crisis, the relevance of the traditional geology field-mapping camp has also been called into question.

Geology field camps typically entail a 6- or 8-week intensive, on-site mapping exercise following the third year in university. Although most geoscientists will agree that field camp was an integral part of their own educational experience, we must evaluate how field camps address the current, evolving needs of our young scientists. This represents an important opportunity for the hydrogeologic community, which is particularly

Received: 7 March 2003 / Accepted: 9 March 2003

Published online: 2 April 2003

(C) Springer-Verlag 2003

F. D. Day-Lewis (

Department of Geology,

Bucknell University,

Lewisburg, PA, 17837, USA

e-mail: fdaylewi@bucknell.edu sensitive to geology's movement towards theoretical and computational research, to help redefine the fieldcamp experience and support the integration of field hydrogeology into geoscience education.

The relevance and role of geology field camp is on the minds of many geoscience educators (see, for example, C.N. Drummond's editorial "Can field camps survive?" J Geosci Educ 49(4):336). At several recent conferences, I sought out colleagues from peer institutions and inquired about the role of field camps in their respective curricula. In return, I shared with them the views of my own department, which strongly encourages students to attend a field camp but does not require that they do so. This policy is based on several factors, including our own field-intensive course content, sensitivity to students' finances, and our tradition of involving students in summer thesis research. As I was expecting, many schools' curricula mandate that students attend a field camp; however, I was surprised to learn how many of these insist that the camp experience be focused solely on geologic mapping. For these schools, camps with significant coverage of hydrogeologic, geophysical, or geochemical field methods do not fulfill the degree requirement. One colleague even informed me that every year his department rejects students' requests to attend "specialized" or "integrated" field camps. Overwhelmingly, the rationale that underlies this constraint is that geologic mapping is fundamental to the science of geology, no matter what geoscientific field a student later pursues. In this paradigm, other field methods are considered specializations better addressed in postgraduate school.

The transition of geology field camps toward incorporation of new technology (e.g., GPS and GIS) and coverage of hydrogeologic, geophysical, and geochemical field methods closely parallels the evolution of geoscience departments in the United States; some are adapting quickly, others reluctantly, and some not at all. Well-established, specialized field experiences focus on topics such as hydrogeology (e.g., University of Minnesota and Western Michigan University), geophysics (such as SAGE, the Summer of Applied Geophysical Experience, sponsored by Los Alamos National Lab), and marine geology (e.g., the International Ocean Drilling Program). Other camps, such as Indiana University's, supplement traditional mapping programs with modules 
on environmental geology and hydrogeology. These field experiences offer students many of the same benefits as traditional field camps, including active-learning experience in how to conduct fieldwork and take field notes, make interpretations based on limited data, visualize the subsurface in three dimensions, and bring a complex project to completion.

Many of the best postgraduate programs in hydrogeology, geophysics, rock mechanics, geochemistry, and petroleum geology accept students with degrees in physics, mathematics, soil science, chemistry, and engineering. Most of these students thrive and succeed in postgraduate school and beyond. In some cases, they would benefit from having additional background in geology, but can we rightly claim that a traditional, geologic-mapping field camp experience would be of fundamental importance to their research and future careers? Not all of our students are drawn to geoscience by a desire to map or to conduct fieldwork at all; some are drawn more to computational geoscience or laboratory research. We cannot afford to discourage these students from entering the geosciences.

Clearly, our discipline faces an urgent need to answer the daunting questions of "What is fundamental geoscience?" and "What is specialization?" For hydrogeology, as for other geoscience subdisciplines, the answers will have far-reaching implications. In some American departments, hydrogeologists are at the vanguard of curricular adaptation and serve to prepare students for careers or postgraduate research in quantitative geoscience. In others, however, they occupy precarious positions, and are perceived as outsiders-engineers in geologists' clothing.

In the United States, we are at an important turning point in geoscience pedagogy, and hydrogeologists must help inform ongoing debates at our institutions or alma maters over what the geology core curriculum should comprise, including what type of field camp students should be encouraged, or required, to attend. We need to support attempts by our departments to provide marketable geoscience skills and to address questions of societal relevance. Our task would be made easier by showing the boundaries between geologic subdisciplines to be gradational rather than discontinuous. The interfaces between hydrogeology and other geological disciplines, such as structural geology, geomorphology, and geochemistry, provide excellent opportunities for us to show that fluid flow, the hydrologic cycle, fluid-rock interaction, and fluids in geologic processes are all as basic and fundamental to geoscience as are strike and dip. Central to our task is encouraging our departments to make a place in the curriculum for alternative field camp experiences. 